\title{
Involvement of Ethylene in Development of Chilling Injury in Fresh-cut Tomato Slices during Cold Storage
}

\author{
Ji Heun Hong and Kenneth C. Gross ${ }^{1}$ \\ Horticultural Crops Quality Laboratory, Building 002, Beltsville Agricultural Research Center, \\ Agricultural Research Service, USDA, 10300 Baltimore Avenue, Beltsville, MD 20705-2350
}

\begin{abstract}
AdDitional INDEX wORDS. Lycopersicon esculentum, chilling injury, minimally processed, water-soaked areas, 1aminoethoxyvinylglycine
\end{abstract}

\begin{abstract}
Experiments were conducted to determine if ethylene influences chilling injury, as measured by percentage of slices exhibiting water-soaked areas in fresh-cut tomato slices of 'Mountain Pride' and 'Sunbeam' tomato (Lycopersicon esculentum Mill.). Ethylene concentration in containers without ventilation significantly increased during storage at $5^{\circ} \mathrm{C}$, whereas little or no accumulation of ethylene occurred in containers with one or six perforations. Chilling injury was greatest for slices in containers with six perforations, compared to slices in containers with one perforation, and was over 13-fold greater than that of slices in control containers with no perforations. An experiment was also performed to investigate the effectiveness of including an ethylene absorbent pad in containers on subsequent ethylene accumulation and chilling injury. While ethylene in the no-pad controls increased continually during storage of both 'Mountain Pride' and 'Sunbeam' tomatoes at $5{ }^{\circ} \mathrm{C}$ under modified atmosphere conditions, no increase in accumulation of ethylene was observed in containers containing ethylene absorbent pads throughout storage. The ethylene absorbent pad treatment resulted in a significantly higher percentage of chilling injury compared with the no-pad control. In studies aimed at inhibiting ethylene production using AVG during storage of slices, the concentration of ethylene in control containers (no AVG) remained at elevated levels throughout storage, compared to containers with slices treated with AVG. Chilling injury in slices treated with AVG was 5-fold greater than that of controls. Further, we tested the effect of ethylene pretreatment of slices on subsequent slice shelf life and quality. In slices treated with ethylene $\left(0,0.1,1\right.$, or $\left.10 \mu \mathrm{L} \cdot \mathbf{L}^{-1}\right)$ immediately after slicing, ethylene production in nontreated controls was greater than that of all other ethylene pretreatments. However, pretreatment of slices 3 days after slicing resulted in a different pattern of ethylene production during storage. The rate of ethylene production by slices treated with $1 \mu \mathrm{L} \cdot \mathrm{L}^{-1}$ ethylene 3 days after slicing was greater during storage than any of the other ethylene treatments. With slices pretreated with ethylene, both immediately and 3 days after slicing, the rate of ethylene production tended to show a negative correlation with chilling injury. Chemical name used: 1-aminoethoxyvinylglycine (AVG).
\end{abstract}

The major symptoms of chilling injury in tomatoes (Lycopersicon esculentum) are uneven ripening, surface pitting, increased fungal infection, and water-soaked areas on red ripe fruit (Hobson, 1987; Rhodes, 1980). Symptoms associated with chilling injury usually appear only upon returning fruit to ambient temperature (King and Ludford, 1983). However, formation of water-soaked areas sometimes occurs while tomatoes are being held in cold storage, without removal of fruit to nonchilling temperatures (Hong and Gross, 1998). Although many researchers have studied chilling injury of whole tomatoes, little attention has been given to fresh-cut tomato slices.

Ethylene is a plant hormone that controls many aspects of plant growth and development, and its rate of production is increased dramatically by various stimuli (Yang and Hoffmann, 1984). Ethylene is synthesized naturally during specific developmental stages such as fruit ripening, seed germination, leaf and flower senescence and abscission, and root and leaf growth. Also, ethylene production is stimulated by various types of stress, including mechanical wounding (bruising and cutting), tempera-

\footnotetext{
Received for publication 26 Aug. 1999. Accepted for publication 10 July 2000. Use of a company or product name by the USDA does not imply approval or recommendation of the product to the exclusion of others which may also be suitable. We would like to express our appreciation to the Korea Science and Engineering Foundation for financial assistance to partially support J.H.H. The cost of publishing this paper was defrayed in part by the payment of page charges. Under postal regulations, this paper therefore must be hereby marked advertisement solely to indicate this fact.

${ }^{1}$ Corresponding author.
}

ture (chilling, freezing, and occasionally high temperature), and chemicals (auxins, herbicides, and various pollutants). Ethylene also accumulates in response to pathogenic infection of plant tissues (Boller and Kende, 1980; Yang and Hoffmann, 1984).

Ethylene is involved in chilling injury in a number of fruits. For example, ethylene treatment increased development of chilling injury symptoms and decreased shelf life of avocado (Persea americana Mill.) (Chaplin et al., 1983). Avocado fruit stored in an atmosphere with high ethylene also showed more chilling injury than those maintained in air at the same temperature (Lee and Young, 1984).

Ethylene has also been shown to alleviate chilling injury. For example, application of ethylene significantly reduced the incidence of chilling injury in 'Honeydew' muskmelons [Cucumis melo L. (Reticulatus Group)] (Lipton and Aharoni, 1979) and exposure of sweet potatoes [Ipomoea batatas (L.) Poir.] ethylene during the postchilling period significantly reduced the severity of chilling injury (Buescher, 1977). In contrast, Kader and Morris (1975) reported that exposure of mature green tomatoes to ethylene before or following storage at chilling temperatures did not affect development of chilling injury.

Little is known about the effect of ethylene on formation of water-soaked areas during chilling injury in tomato fruit, especially with regard to fresh-cut slices. While studying storage of fresh-cut tomato at low temperatures, we observed that ethylene affected development of chilling injury in tomato slices under modified atmosphere (MA) storage. Therefore, the objective of this study was to investigate the involvement of ethylene in chilling injury of fresh-cut tomato slices. 


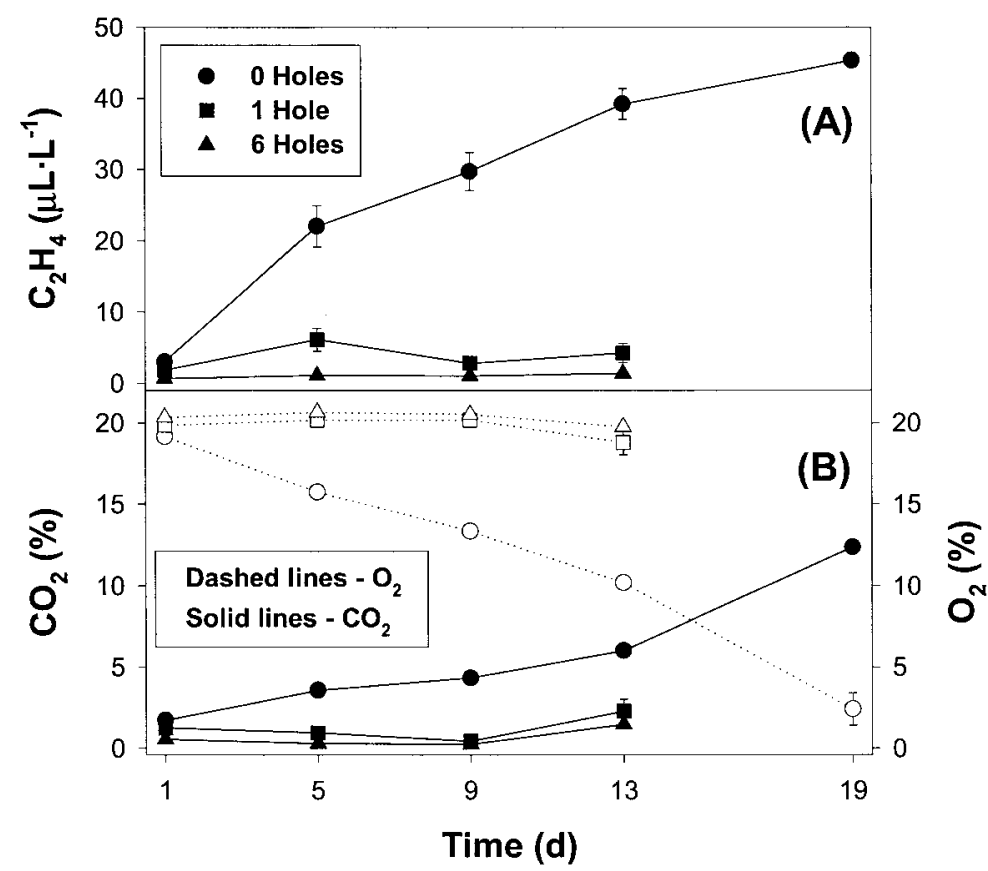

Fig. 1. (A) Changes in ethylene and (B) $\mathrm{CO}_{2}$ and $\mathrm{O}_{2}$ concentrations in containers with fresh-cut slices from red 'Sunbeam' tomatoes during storage at $5^{\circ} \mathrm{C}$. Slices were placed into 1-L plastic containers, sealed, and then holes were made using a syringe needle (22G; $0.7 \mathrm{~mm}$ diameter). Each symbol represents the mean of three observations. Vertical bars represent \pm 1 SD.

\section{Materials and Methods}

'Sunbeam' and 'Mountain Pride' tomatoes were grown during 1999 at the South Farm of the Beltsville Agricultural Research Center, Beltsville, Md. For some experiments, tomatoes were obtained from Maryland Tomato Company (Jessup, Md.). To remove field heat and obtain fruit of uniform color, fruit were stored at $20^{\circ} \mathrm{C}$ for $24 \mathrm{~h}$ and then hand selected visually for study based on surface color when they had reached the light red and red-ripe stage of ripeness. Fruit were selected that were free of visual defects and uniform in size.

Fruit were washed with tap water and then air dried. Five to six slices ( $7 \mathrm{~mm}$ thick) were cut from the stem end with a meat slicer (model 827; Berkel, Inc., Ind.). The fourth slice from the stem end of each of four tomatoes was placed in a 1-L plastic fresh-cut produce container for MA storage and sealed using LDX 5406 film (Cryovac, N.Y.) which had an oxygen transmission rate (OTR) per atmosphere of $14.4 \mathrm{~mL} \cdot \mathrm{d}^{-1} \cdot \mathrm{m}^{-2}$ at $5{ }^{\circ} \mathrm{C}$ and $99 \%$ relative humidity $(\mathrm{RH})$ and then held at $5{ }^{\circ} \mathrm{C}$.

In studying the effect of ethylene on chilling injury, four experiments were conducted to evaluate 1) the effect of container ventilation, 2) use of an ethylene absorbent pad (EAP) containing $\mathrm{KMnO}_{4}$ in the container, 3 ) treatment of slices $(\approx 150 \mathrm{~g})$ with $2.5 \mathrm{~mL}$ of $1 \mathrm{~g} \cdot \mathrm{L}^{-1} \mathrm{AVG}$ before sealing, and 4) gassing with ethylene. In the ventilation experiments, one or six evenly-spaced holes were made in the sealed film using a syringe needle $(22 \mathrm{G}, \approx 0.7 \mathrm{~mm}$ diameter). For ethylene exposure, slices cut from light-red tomato fruit were stored, at both 0 and $3 \mathrm{~d}$ after cutting, in containers with $0.1,1$, or $10 \mu \mathrm{L} \cdot \mathrm{L}^{-1}$ ethylene at a flow rate of $20 \mathrm{~mL} \cdot \mathrm{min}^{-1}$ for $4 \mathrm{~h}$. In slices treated with ethylene $3 \mathrm{~d}$ after slicing, slices were placed at $5^{\circ} \mathrm{C}$ in air before ethylene exposure.

To analyze the level of accumulated ethylene, $\mathrm{O}_{2}$ or $\mathrm{CO}_{2}$ in containers during storage, $5 \mathrm{~mL}$ of headspace gas was taken from each container periodically for analysis using a gas chromatograph (HP 5890; Hewlett Packard, Baltimore, Md.) or a $\mathrm{O}_{2} / \mathrm{CO}_{2}$ analyzer (AMETEK, Pittsburgh, Pa.). Chilling injury, defined herein as presence of water-soaked areas, was expressed as a percentage of slices clearly showing symptoms, i.e., number of slices with water-soaked areas divided by the total number of slices investigated multiplied by 100 . When water-soaked areas did appear in tomato slices, at least $50 \%$ of the tissue became transparent. Thus, we determined that slices with at least $50 \%$ of their total area water soaked were deemed to have chilling injury and slices showing $<5 \%$ were considered not to have chilling injury. There were no slices showing 5\% to 50\% water-soaked areas in our experiments. For ethylene production rate, individual fruit slices were placed in 1$\mathrm{Ljars}$ at $5^{\circ} \mathrm{C}$. Ethylene and $\mathrm{CO}_{2}$ production were monitored using an automatic sampling, flow-through system (Watada and Massie, 1981).

\section{Results}

First, we compared ethylene accumulation in containers with zero, one or six ventilation holes to determine if ethylene had an effect on chilling injury in fresh-cut tomato slices during storage. Ethylene concentration in containers without ventilation significantly increased during storage, while there was little and no

Table 1. Effect of package film ventilation and inclusion of ethylene absorbent pads (EAP) on chilling injury and visible fungal growth of slices from red tomato fruit. Four slices were placed into each plastic container, heat-sealed with film and holes were then made using a syringe needle (22G; $0.7 \mathrm{~mm}$ diameter). Ethylene absorbent pads were placed into containers before heat-sealing. Packages were held at $5^{\circ} \mathrm{C}$.

\begin{tabular}{|c|c|c|c|c|}
\hline Cultivar & Days $^{z}$ & $\begin{array}{c}\text { Slices } \\
\text { (no.) }\end{array}$ & Treatment & $\begin{array}{c}\text { Chilling } \\
\text { injury } \\
(\%)^{\mathrm{y}}\end{array}$ \\
\hline \multirow[t]{3}{*}{ Sunbeam } & 13 & 16 & Control $^{\mathrm{x}}$ & 6 \\
\hline & & & 1 Hole & 43 \\
\hline & & & 6 Holes & 81 \\
\hline \multirow[t]{2}{*}{ Sunbeam } & 17 & 28 & Control & 0 \\
\hline & & & EAP & 46 \\
\hline \multirow[t]{2}{*}{ Mountain Pride } & 17 & 28 & Control & 42 \\
\hline & & & EAP & 89 \\
\hline
\end{tabular}

${ }^{\mathrm{z}}$ Number of days slices were held in cold storage.

${ }^{y}$ Number of slices with symptoms/total number of slices $\times 100$.

${ }^{\mathrm{x}}$ No holes or ethylene absorbent pads. 


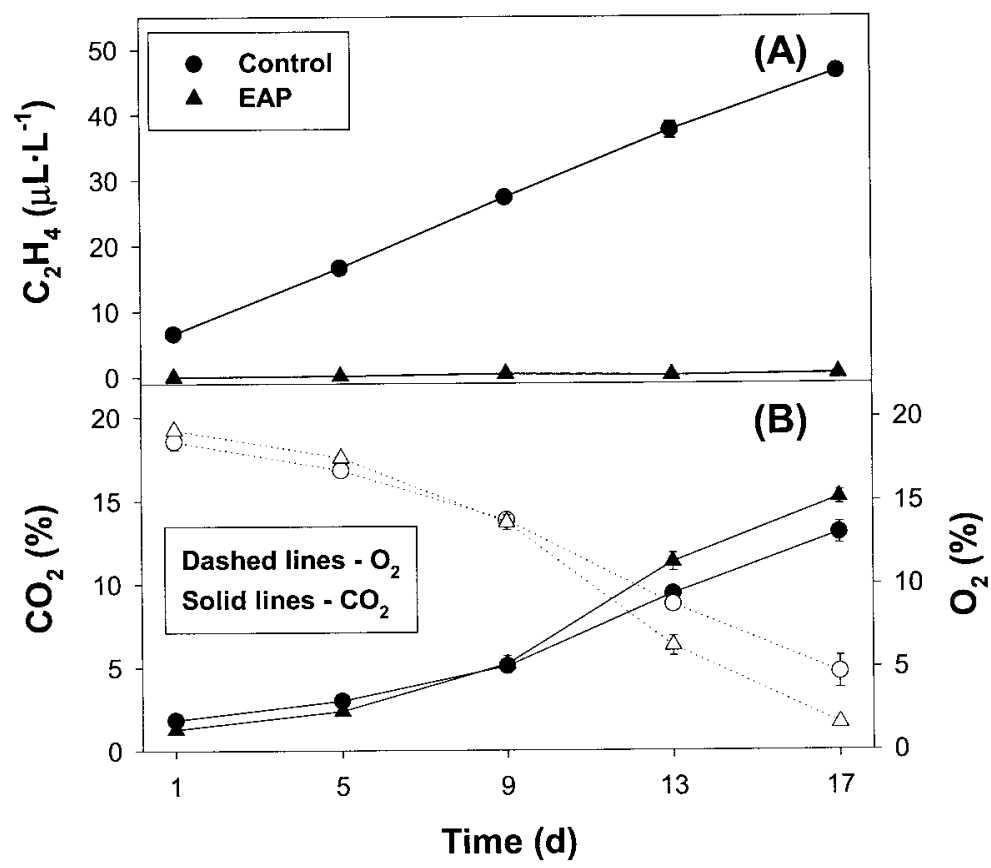

Fig. 2. (A) Changes in ethylene and (B) $\mathrm{CO}_{2}$ and $\mathrm{O}_{2}$ concentrations in containers with fresh-cut slices from red 'Sunbeam' tomatoes during storage at $5^{\circ} \mathrm{C}$. Slices were placed into plastic containers without (control) or with an ethylene absorbent pad (EAP) and sealed. Each symbol represents the mean of four observations. Vertical bars represent \pm 1 SD.

accumulation of ethylene in containers with one and six holes, respectively (Fig. 1A). Measurement of the atmospheric composition in containers showed that $\mathrm{CO}_{2}$ and $\mathrm{O}_{2}$ in both containers with one hole and containers with six holes were maintained at $1 \%$ and $20 \%$, respectively, during storage (Fig. 1B). Carbon dioxide and $\mathrm{O}_{2}$ in containers without ventilation increased gradually or decreased, respectively, during storage.

A significant difference in percentage of slices showing chilling injury was observed among the control and other treatments after $13 \mathrm{~d}$ storage at $5^{\circ} \mathrm{C}$ (Table 1$)$. Chilling injury of slices in containers with six holes was most severe, being 2-fold and 13-fold higher than that of slices in containers with one and no holes, respectively.

There were significant differences in ethylene, $\mathrm{CO}_{2}$, and $\mathrm{O}_{2}$ concentrations among the various ventilation treatments (Fig. 1A and B). Therefore, it was not clear whether accumulation of ethylene, $\mathrm{CO}_{2}$, or $\mathrm{O}_{2}$ in containers had an effect on development of chilling injury. Thus, ethylene absorbent pads were placed in containers to create an atmosphere differing only in ethylene concentration. The same experiment was conducted using both 'Sunbeam' and 'Mountain Pride' tomatoes. In 'Sunbeam,' while ethylene in controls (no-pad) increased continually during storage at $5{ }^{\circ} \mathrm{C}$ under modified atmosphere, no increase in accumulation of ethylene was observed in containers with an ethylene absorbent pad throughout storage (Fig. 2A). Accumulation of $\mathrm{CO}_{2}$ in both controls and containers with ethylene absorbent pads increased steadily, and $\mathrm{O}_{2}$ concentration, regardless of treatment, continued to decline during storage (Fig. 2B). There were no differences in the atmospheric concentration between controls and containers with ethylene absorbent pads for up to $9 \mathrm{~d}$ storage. However, differences in $\mathrm{CO}_{2}$ and $\mathrm{O}_{2}$ were observed between controls and containers with an ethylene absorbent pad thereafter. Use of ethylene absorbent pads resulted in significantly higher chilling injury, compared to controls after $17 \mathrm{~d}$ storage at $5{ }^{\circ} \mathrm{C}$ (Table 1 ). For 'Mountain Pride,' both controls and containers with ethylene absorbent pads had similar trends in ethylene, $\mathrm{CO}_{2}$, and $\mathrm{O}_{2}$ concentrations during storage, as compared to 'Sunbeam' (Fig. 3A and B). The percentage of chilling injury in controls was significantly less than that of slices in containers with ethylene absorbent pads after $17 \mathrm{~d}$ storage at $5{ }^{\circ} \mathrm{C}$ (Table 1$)$.

Despite a transient wound response after $2 \mathrm{~d}$ storage, the rate of ethylene production of slices from red ripe 'Mountain Pride' tomatoes decreased gradually until $\approx 6 \mathrm{~d}$ storage and then increased steadily up to $15 \mathrm{~d}$ storage (Fig. 4A). Slices from red 'Sunbeam' tomatoes showed a similar trend to 'Mountain Pride' in ethylene production during storage. However, after $5 \mathrm{~d}$ storage, the rate of ethylene production of 'Sunbeam' slices was higher than the rate of slices from 'Mountain Pride' tomatoes. For both 'Sunbeam' and 'Mountain Pride' tomatoes, there was an initial sharp decrease in respiration, followed by a slight decline or steady state equilibration in respiration (Fig. 4B); after $10 \mathrm{~d}$ storage, $\mathrm{CO}_{2}$ production then increased gradually. There was little or no difference in the rate of $\mathrm{CO}_{2}$ production between 'Sunbeam' and 'Mountain Pride' tomatoes after 13 d storage.

For both control and AVG treatment, there was a continuous increase in ethylene concentration in containers during storage at $5{ }^{\circ} \mathrm{C}$ under modified atmospheres (Fig. 5A). However, the concentration of ethylene in controls was higher than that in containers with slices treated with AVG throughout the storage period. After $19 \mathrm{~d}$ storage at $5^{\circ} \mathrm{C}$, chilling injury of slices treated with AVG was 5-fold greater than controls (Fig. 5B).

To test the effect of ethylene treatment after the wound

Fig. 3. (A) Changes in ethylene and (B) $\mathrm{CO}_{2}$ and $\mathrm{O}_{2}$ concentrations in containers with fresh-cut slices from red 'Mountain Pride' tomatoes during storage at $5^{\circ} \mathrm{C}$. Slices were placed into plastic containers without (control) or with an ethylene absorbent pad (EAP) and sealed. Each symbol represents the mean of four observations. Vertical bars represent \pm 1 SD.

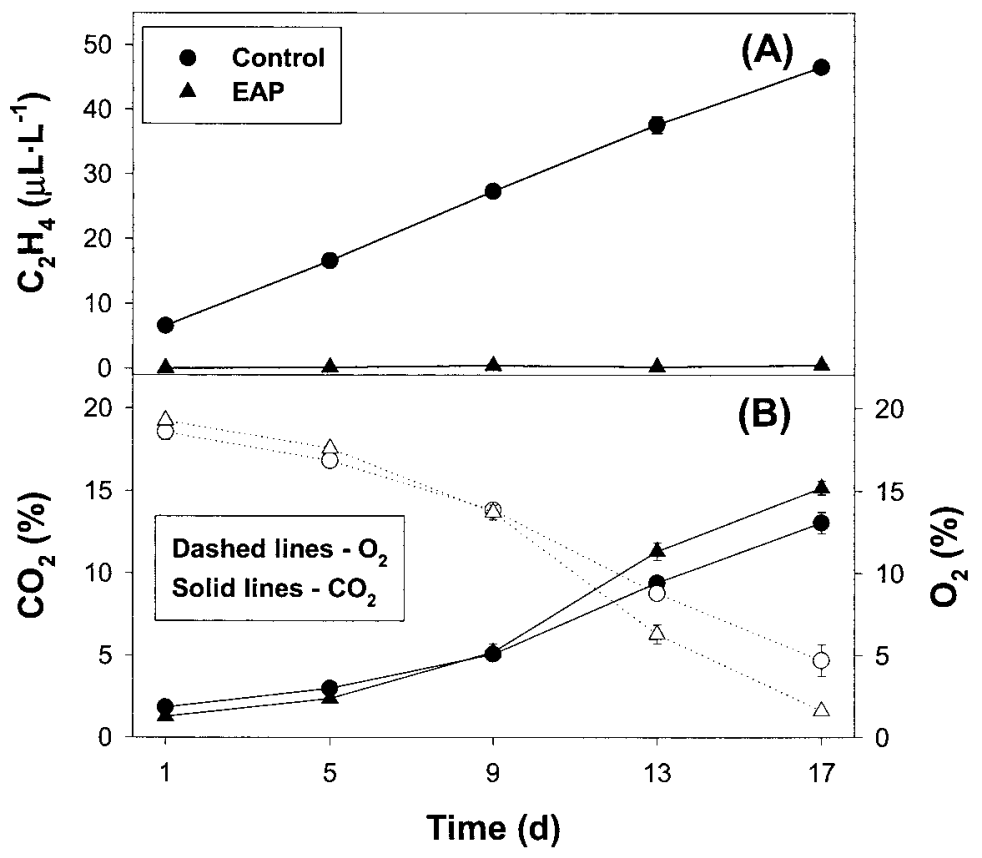




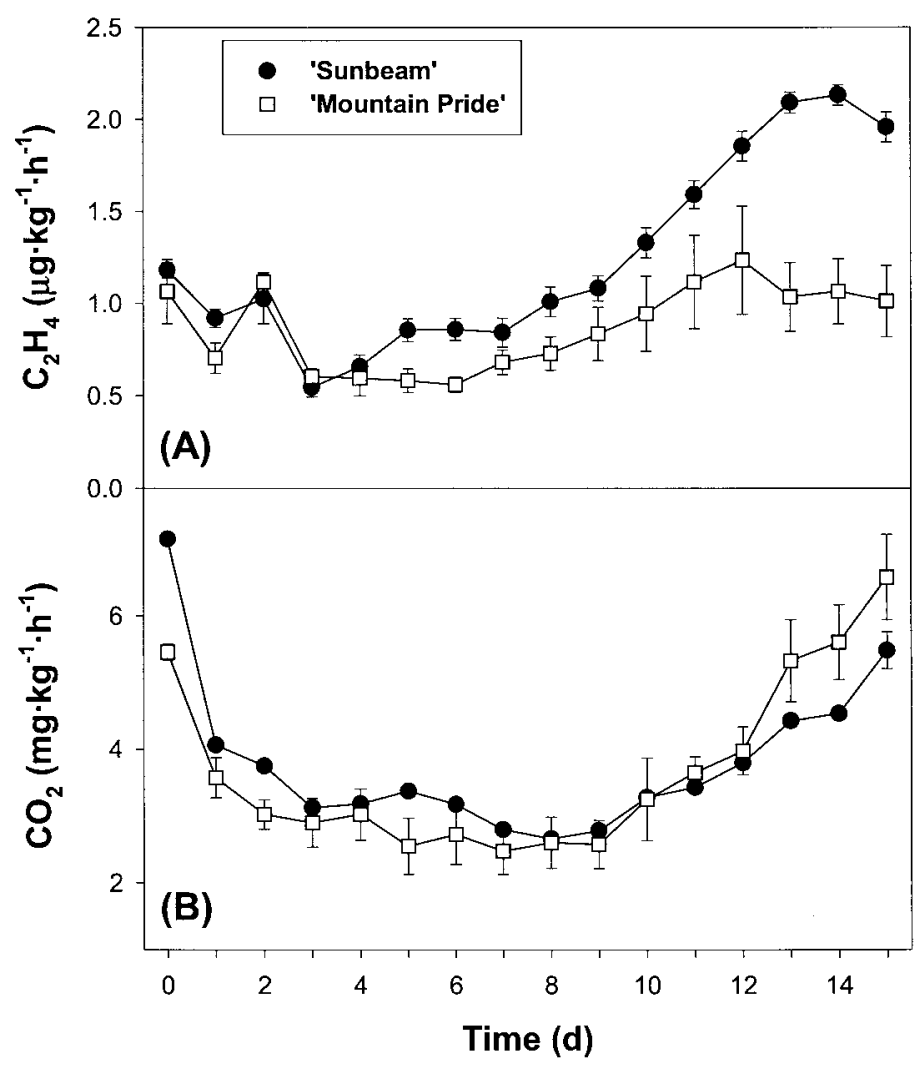

Fig. 4. (A) Changes in the rate of ethylene and (B) $\mathrm{CO}_{2}$ production of fresh-cut slices from red 'Sunbeam' and 'Mountain Pride' tomatoes during storage at $5{ }^{\circ} \mathrm{C}$. Slices were placed into 1-L gas-tight containers. The rates of ethylene and $\mathrm{CO}_{2}$ production were measured by gas chromatography using a continuous flow system. Each symbol represents the mean of four observations. Vertical bars represent $\pm 1 \mathrm{SD}$.

response, slices were treated with different concentrations of ethylene for $4 \mathrm{~h}$ either immediately or $3 \mathrm{~d}$ after slicing. In slices treated with ethylene immediately after slicing, all slices showed at most a gradual decline in ethylene production until $5 \mathrm{~d}$. Then, only relatively small changes were observed, with the exception of slices from controls (Fig. 6A). Subsequently, the rate of ethylene production of slices treated with 0.1 or $10 \mu \mathrm{L} \cdot \mathrm{L}^{-1}$ remained above the rates of slices treated with $1 \mu \mathrm{L} \cdot \mathrm{L}^{-1}$, and there was no difference in ethylene production of slices between 0.1 and $10 \mu \mathrm{L} \cdot \mathrm{L}^{-1}$. Ethylene production of controls was greater than all other treatments. However, the rate of ethylene production of slices treated with $1 \mu \mathrm{L} \cdot \mathrm{L}^{-1}$ ethylene at $3 \mathrm{~d}$ after slicing was the highest during storage (Fig. 6C).

Slices treated with $10 \mu \mathrm{L} \cdot \mathrm{L}^{-1}$ ethylene $3 \mathrm{~d}$ after slicing had greater ethylene production than controls or slices treated with $0.1 \mu \mathrm{L} \cdot \mathrm{L}^{-1}$ ethylene during the rise in ethylene production. With both slices treated with ethylene immediately or $3 \mathrm{~d}$ after slicing, the rate of ethylene production showed was related to the severity of water-soaked areas, i.e., chilling injury. For slices treated with various concentrations of ethylene immediately after slicing, chilling injury of slices treated with $1 \mu \mathrm{L} \cdot \mathrm{L}^{-1}$ ethylene was highest after $13 \mathrm{~d}$ storage, compared to slices given the other treatments (Fig. 6B). Control slices had the least chilling injury. In slices treated with ethylene $3 \mathrm{~d}$ after slicing, chilling injury of controls was 2-fold greater than that of slices treated with ethylene after $13 \mathrm{~d}$ storage (Fig. 6D).

\section{Discussion}

Hobson (1987) observed that with tomato fruit stored at 5 to $7.5{ }^{\circ} \mathrm{C}$ for $9 \mathrm{~d}$ in air, moderate chilling injury sometimes occurred in the form of translucent water-soaked patches on an otherwise red fruit, whereas slightly chilling-injured tomato fruit showed development of mealiness and loss of firmness. Our results support those observations. We found that mealiness occurred in slices before the appearance of translucent watersoaked areas (data not presented). However, the visible symptoms of mealiness did not become apparent, as much as it can be used as an indicator of chilling injury, compared to watersoaked areas. Thus, severity of water-soaked areas was used as an indicator to express the degree of chilling injury.

Morris (1982) proposed that development of water-soaked areas, a visible symptom of chilling injury, resulted from exudation of cellular fluids into the intracellular space, caused by loss of membrane integrity and cellular breakdown. Lyons and Raison (1970) suggested that the primary event in chilling injury is an alteration of the plasma membrane into a less fluidgel state, leading to metabolic imbalances, decompartmentation, and a subsequent increase in leakage of ions and water.

Fig. 5. (A) Changes in ethylene concentration in containers with fresh-cut slices from red tomatoes throughout storage and $(\mathbf{B})$ percentage of chilling injury after $19 \mathrm{~d}$ storage at $5^{\circ} \mathrm{C}$. Fresh market tomatoes (cultivar unknown) were obtained from Maryland Tomato Company (Jessup, Md.). Four slices, weighing $\approx 150 \mathrm{~g}$, were sprayed on both cut surfaces with $2.5 \mathrm{~mL}$ water without (control) or with $1 \mathrm{~g} \cdot \mathrm{L}^{-1} \mathrm{AVG}$ and placed into $1-\mathrm{L}$ plastic containers which were then sealed. In A, each symbol represents the mean of four observations and in B each value is based on 24 observations. In A, vertical bars represent \pm 1 SD.

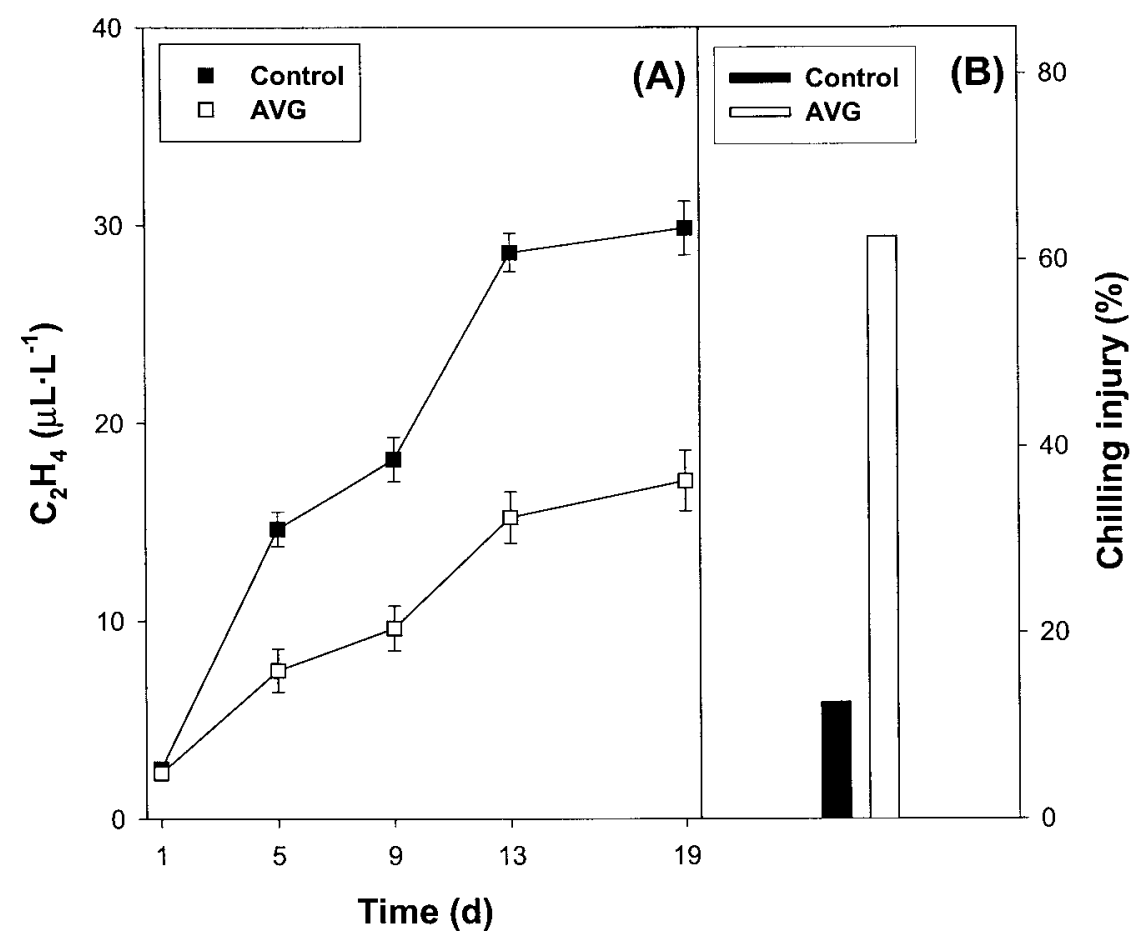




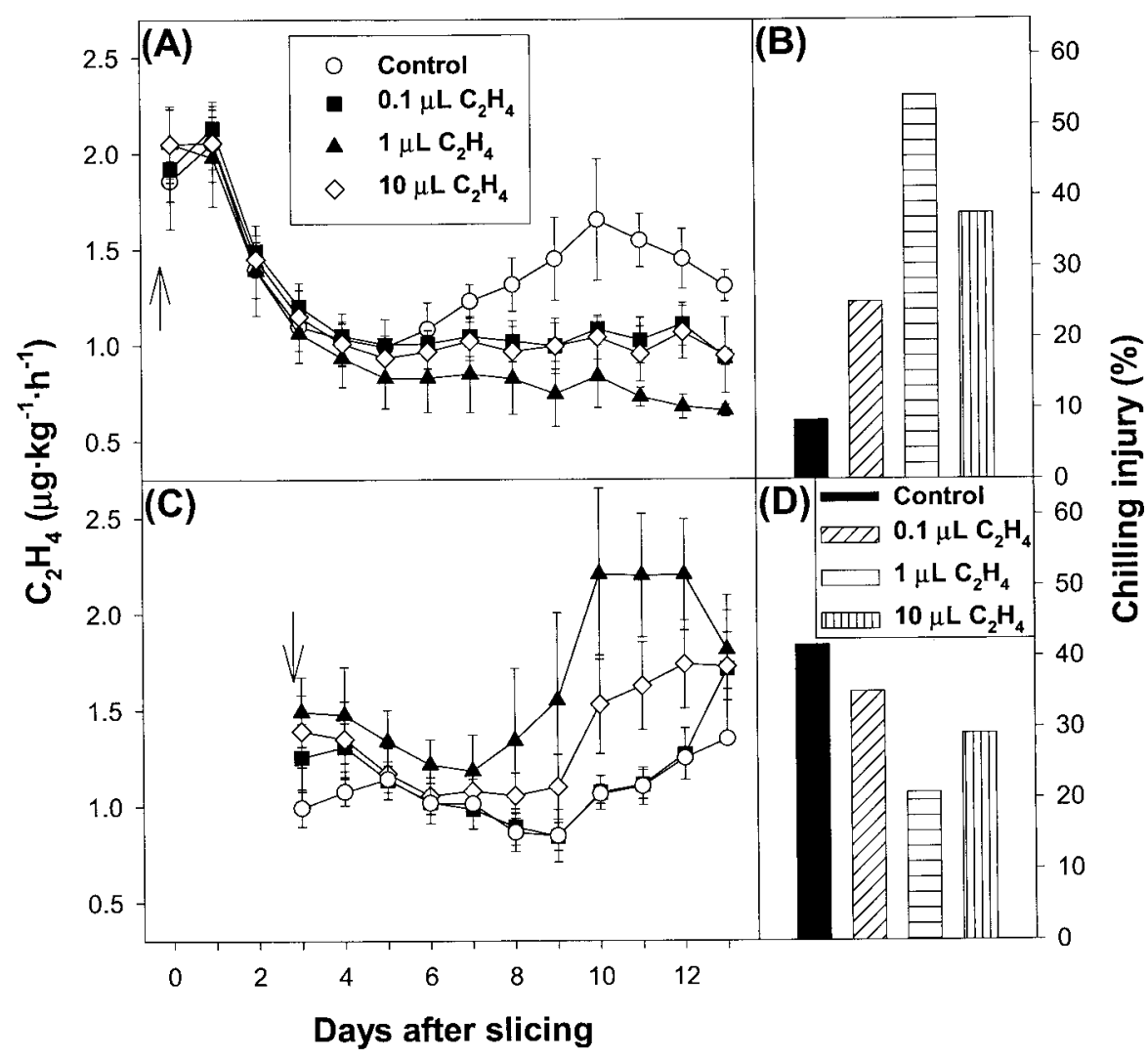

loss of cell turgor and subsequent development of water-soaked areas.

It was observed that cucumbers ( $\mathrm{Cucu}$ mis sativus L.) stored at $5{ }^{\circ} \mathrm{C}$ for $7 \mathrm{~d}$ developed pitting at $50 \%$ to $60 \% \mathrm{RH}$, while pitting was prevented at $95 \%$ to $100 \%$ (Morris and Platenius, 1938). Wardowski et al.(1973) reported that increasing the humidity in the storage environment reduced chilling injury in lime [Citrus aurantifolia (Christm.) Swingle] and grapefruit (Citrus $\times$ paradisi Macfad.). Murata (1969) observed that brown substances were present around the vascular tissues of the peel of fruits injured by chilling, and that they increased in number with the progression of chilling injury. Similarly, in the present study with tomato slices, we observed that chilling injury, i.e., water-soaked areas, appeared first in tissue surrounding vascular tissue.

We are unaware of reports on the effect of ethylene on chilling injury in fresh-cut tomato slices. Tomato slices in containers with high ethylene concentration had a reduced development of water-soaked areas than those in containers with low ethylene during storage at $5^{\circ} \mathrm{C}$ under modified atmosphere (Figs. 1, 2, and 3; Table 1). Also, reduction in the accumulation of ethylene in

Fig. 6. Effect of exogenous ethylene treatment for $(\mathbf{A}) 0 \mathrm{~d}$ or $(\mathbf{C}) 3 \mathrm{~d}$ on the rate of subsequent ethylene production by fresh-cut slices from light red tomatoes during storage at $5{ }^{\circ} \mathrm{C}$, and the effect of exogenous ethylene treatment for $(\mathbf{B}) 0 \mathrm{~d}$ or $(\mathbf{D})$ $3 \mathrm{~d}$ on the percentage of chilling injury after $13 \mathrm{~d}$ storage at $5{ }^{\circ} \mathrm{C}$. Fresh market tomatoes (cultivar unknown) were obtained from Maryland Tomato Company (Jessup, Md.). Slices were treated with 0 (control), $0.1,1$, or $10 \mu \mathrm{L} \cdot \mathrm{L}^{-1}$ ethylene for $4 \mathrm{~h}$ using a continuous flow system at a flow rate of $20 \mathrm{~mL} \cdot \mathrm{min}^{-1}$ either 0 (immediately) or $3 \mathrm{~d}$ after slicing. Slices used for measurement of ethylene production were placed into 1-L gas-tight containers. The rate of ethylene production was measured by gas chromatography using a continuous flow system. The arrows indicate the time of exogenous ethylene treatment. In A and $\mathrm{C}$ each symbol represents the mean of three observations and vertical bars represent \pm 1 SD. In B and D, each value represents the mean of 24 observations.

Formation of mealiness has been attributed to altered solubilization of cell wall pectin (Dawson et al., 1992), resulting from an imbalance in cell wall metabolism, due to an increase in pectinesterase (PE; pectin pectyl hydrolase; E.C. 3.1.1.11) activity and inhibition of polygalacturonase (PG; endo- $\alpha-1,4-$ galacturonan hydrolase; E.C. 3.2.1.15.) activity at cold storage temperatures (Ben-Arie and Sonego, 1980). It was also suggested that an increase in pectin demethylation, due to higher than normal PE activity during chilling, increased the number of free carboxyl groups available for binding with free water (Buescher and Furmanski, 1978; Jackman et al., 1992a), who postulated that this reduction in the amount of unbound water may result in the development of mealiness.

We found that mealy slices with water-soaked areas were $50 \%$ softer than those slices without chilling injury (data not presented). Because a loss in cellular turgor pressure could be responsible for chilling-associated softening (Jackman et al., 1992 a,b), it was possible that with the progression of chilling injury, the movement of water from the cytosol into the apoplast, due to a limited number of sites for binding of cytosolic free water and cold-induced membrane breakdown, would contribute to the

packages during storage, through the use of AVG treatment, induced the development of chilling injury symptoms (Fig. 5). In addition, when ethylene treatments were given immediately or 3 $\mathrm{d}$ after slicing, exogenous ethylene treatment had an opposite effect on the rate of ethylene production during subsequent storage. In both experiments, slices with the highest rate of ethylene production had the lowest percentage of slices with water-soaked areas (Fig. 6). These results suggest that ethylene may inhibit development of chilling injury in tomato during low temperature storage.

Treatment of 'Honey Dew' musk melon with ethylene at $20^{\circ} \mathrm{C}$ before transfer to 2.5 or $5^{\circ} \mathrm{C}$ significantly reduced chilling injury (Lipton and Aharoni, 1979). However, Wang (1987) showed that the elimination of ethylene production by treatment with aminooxyacetic aicd (AOA) did not affect chilling injury. In addition, treatment with 1-aminocyclopropane-1-carboxylic acid (ACC) or ethylene before, during, or after chilling did not influence chilling injury symptoms in cucumber seedlings (Wang, 1989).

Slices from 'Sunbeam' and 'Mountain Pride' tomatoes showed their lowest rate of ethylene production 2 and $4 \mathrm{~d}$ before the rise in autocatalytic ethylene, respectively (Fig. 4A). In cucumber fruit, chilling-induced ethylene production was reduced after a prolonged duration of chilling temperature exposure (Anderson, 1986). Wang and Adams (1982) reported that cucumbers held for $4 \mathrm{~d}$ or longer at $2.5^{\circ} \mathrm{C}$ showed a large increase in ACC levels, but only little ethylene production. This suggested that the conversion of ACC to ethylene was inhibited by prolonged exposure to the chilling temperature. In the present study, tomato slices clearly responded differently than cucumber tissue, in that ethylene increased in cold storage up to $15 \mathrm{~d}$ storage. Ethylene production during chilling stress may be tissue and/or species dependent. 
While $42 \%$ of slices from 'Mountain Pride' tomatoes after 17 d storage had water-soaked areas, no slices from 'Sunbeam' tomatoes had such chilling injury symptoms (Table 1). Also, there was a significant difference in the increase in the rate of ethylene production between 'Sunbeam' and 'Mountain Pride' tomatoes (Fig. 4A). Slices from 'Sunbeam' tomatoes had a greater rate of ethylene production than 'Mountain Pride' tomatoes from the middle to end of the chilling period. These results suggest that accumulation of ethylene in containers not only inhibits development of chilling injury in fresh-cut tomato slices, but could also be used as an indicator to determine the degree of chilling sensitivity. However, it is not known whether ethylene directly modifies the sensitivity of fresh-cut tomato slices to chilling. Therefore, further studies are needed to understand the basis of the relationship between ethylene and chilling sensitivity.

\section{Literature Cited}

Anderson, C.R. 1986. Rapid synthesis of ACC and ethylene by chillingstressed cucumber fruit. HortScience 21:858-859.

Ben-Arie, R. and L. Sonego. 1980. Pectolytic enzyme activity involved in woolly breakdown of stored peaches. Phytochemistry 19:25532555.

Boller, T. and H. Kende. 1980. Regulation of wound ethylene synthesis in plant. Nature 286:259-260.

Buescher, R.W. 1977. Hard core in sweet potato roots as influenced by cultivar, curing, and ethylene. HortScience 12:326-327.

Buescher, R.W. and R.J. Furmanski. 1978. Role of pectinesterase and polygalacturonase in the formation of woolliness in peaches. J. Food Sci. 43:264-266.

Chaplin, G.R., R.B.H. Wills, and D. Graham. 1983. Induction of chilling injury in stored avocados with exogenous ethylene. HortScience 18:952953.

Dawson, D.M., L.D. Melton, and C.B. Watkins. 1992. Cell wall changes in nectarines (Prunus persica): Solubilization and depolymerization of pectic and neutral polymers during ripening and in mealy fruit. Plant Physiol. 100:1203-1210.

Hobson, G.E. 1987. Low-temperature injury and the storage of ripening tomatoes. J. Hort. Sci. 62:55-62.

Hong, J.H. and K.C. Gross. 1998. Surface sterilization of whole tomato fruit with sodium hypochlorite influences subsequent postharvest behavior of fresh-cut slices. Postharvest Biol. Technol. 13:51-58.

Jackman, R.L., H.J. Gibson, and D.W. Stanley. 1992a. Effects of chilling on tomato fruit texture. Physiol. Plant 86:600-608.

Jackman, R.L., A.G. Marangoni, and D.W. Stanley. 1992b. The effects of turgor pressure on puncture and viscoelastic properties of tomato tissue. J. Texture Studies 23:491-505.

Kader, A.A. and L.L. Morris. 1975. Amelioration of chilling injury symptoms on tomato fruits. HortScience 10:324-325.

King, M.M. and P.M. Ludford. 1983. Chilling injury and electrolyte leakage in fruit of different tomato cultivars. J. Amer. Soc. Hort. Sci. 108:74-77.

Lee, S.K. and R.E. Young. 1984. Temperature sensitivity of avocado fruit in relation to $\mathrm{C}_{2} \mathrm{H}_{4}$ teatment. J. Amer. Hort. Sci. 109:689-692.

Lipton, W.J. and Y. Aharoni. 1979. Chilling injury and ripening of 'Honey Dew' muskmelons stored at 2.5 or $5^{\circ} \mathrm{C}$ after ethylene treatment at $20^{\circ} \mathrm{C}$. J. Amer. Soc. Hort. Sci. 104:327-330.

Lyons, J.M. and J.K. Raison. 1970. Oxidative activity of mitochondria isolated from plant tissues sensitive and resistant to chilling injury. Plant Physiol. 45:386-389.

Morris, L.L. 1982. Chilling injury of horticultural crops: An overview. HortScience 17:161-162.

Morris, L.L. and H. Platenius. 1938. Low temperature injury to certain vegetables. Proc. Amer. Soc. Hort. Sci. 36:609-613.

Murata, T. 1969. Physiological and biochemical studies of chilling injury in bananas. Physiol. Plant. 22:401-411.

Rhodes, M.J.C. 1980. Chilling injury-Some underlying biochemical mechanisms, p. 377-393. In: M. Sharom, C. Willemot, and J.E. Thompson (eds.). 1994. Chilling injury induces lipid phase changes in membranes of tomato fruit. Plant Physiol. 105:305-308.

Wang, C.Y. 1987. Changes of polyamines and ethylene in cucumber seedlings in response to chilling stress. Physiol. Plant. 69:253-257.

Wang, C.Y. 1989. Relation of chilling stress to ethylene production, p. 177-189. In: P.H. Li (ed.). Low temperature stress physiology in crops. CRC Press, Boca Raton, Fla.

Wang, C.Y. and D.O. Adams. 1982. Chilling-induced ethylene production in cucumbers (Cucumis sativus L.) Plant Physiol. 69:424-427

Wardowski, W.F., W. Grierson, and G.J. Edwards. 1973. Chilling injury of stored limes and grapefruit as affected by differentially permeable films. HortScience 8:173-175.

Watada, A.E. and D.R. Massie. 1981. A compact automatic system for measuring $\mathrm{CO}_{2}$ and $\mathrm{C}_{2} \mathrm{H}_{4}$ evolution by harvested horticultural crops. HortScience 16:39-41.

Yang, S.F. and N.E. Hoffman. 1984. Ethylene biosynthesis and its regulation in higher plants. Annu. Rev. Plant Physiol. 35:155-189. 